\title{
PIERWSZE PIASTOWSKIE KRÓLESTWO
}

\author{
ZBIGNIEW DALEWSKI \\ Instytut Historii im. Tadeusza Manteuffla Polskiej Akademii Nauk \\ E-mail: zbigdal@gmail.com
}

\begin{abstract}
The first Kingdom of Piasts

The paper aims to reevaluate the ideological and theological questions connected with the first two coronations of the Piast rulers. The author tries to present the actions of Polish kings-to-be as a possible redefinition of their position within the recreated medieval Roman empire (not against it as a more traditional view puts it). Very important role plays the utilization of Holy Lance, or its copy possessed by the Polish rulers. Author uses especially the written accounts of Thietmar's Chronicle put in certain antithesis with the only positive contemporary description of Mieszko II's kingship - the letter written (or stylized) by Matilda of Swabia. The kingship of Piasts is described rather as a religious and ideological, rather than political act.
\end{abstract}

Keywords: kingdom; kingship; Poland; Mieszko II; Boleslav the Valiant

Pierwsze koronacje piastowskie, jak wiadomo, spotkały się w Rzeszy z wrogim przyjęciem. W rocznikach kwedlinburskich znajdujemy pod rokiem 1025 informację o tym, że książę Polaków Bolesław, dowiedziawszy się o śmierci cesarza Henryka, uniesiony pychą ośmielił się namaścić i zuchwale nałożył sobie koronę. Jednak Bóg szybko ukarał jego pychę, gdyż wkrótce po tym zmarł. Niemniej po nim wstąpił na tron jego syn Mieszko, który również nadęty był pychą ${ }^{1}$. W podobny sposób wydarzenia związane z królewskimi wyniesieniami pierwszych Piastów opisał biograf cesarza Konrada II, Wipon. W jego relacji mowa jest o przywłaszczeniu sobie przez Bolesława z krzywdą Konrada insygniów i tytułu królewskiego. Wspomina się też o jego rychłej śmierci i przejęciu władzy po nim przez równie buntowniczego jak on jego syna, Mieszka².

1 Annales Quedlinburgenses, wyd. Martina GIESE (MGH Scriptores rerum Germanicarum in usum scholarum separatim editi. Vol. 72). Hannover 2004, s. 578 n.: „Bolitzlawo dux Poloniae obitu Heinrici imperatoris augusti comperto elatus animo viscere tenus superbiae veneno perfunditur, ade ut uncto etiam sibi imponi coronam temere sit usurpatus. Quam animi sui praesumptionis audaciam divina mox subsecuta est ultio. In brevi namque tristem mortis sententiam compulsus est subito. Post hunc filius eius Misuka natu maior haud dissimili superbia tumens virus arrogantiae longe lateque diffundit."

2 Wiponis Gesta Chuonradi II. imperatoris, wyd. Harry BRESSLAU (MGH Scriptores rerum Germanicarum in usum scholarum separatim editi. Vol. 61). Hannover/Leipzig 1915, s. 31 n. (Kap. 9): „Eodem anno quem supra notavimus Bolizlaus Sclavigena, dux Bolanorum, insignia regalia et regium nomen in iniuriam regis Chuonradi sibi aptavit, cuius temeritatem cito mors exinanivit. Filuis autem eius Misico, similiter rebellis, fratrem suum Ottonem, quoniam regis partibus favebat, in Ruzziam provinciam pepulit." 
Zawarta w obu przywołanych przekazach negatywna ocena piastowskich koronacji była $\mathrm{z}$ pewnością podzielana nie tylko przez ich autorów. $\mathrm{W}$ formułowanych przez nich oskarżeniach pod adresem polskich władców wydaje się pobrzmiewać echo poglądów, do których skłaniała się znaczna część elit politycznych Rzeszy, w tym także dwór cesarski. Nie ulega bowiem wątpliwości, że kwestii tytułu królewskiego Piastów przypadało niezwykle istotne miejsce w dzielącym Polskę i Rzeszę na przełomie lat dwudziestych i trzydziestych XI wieku konflikcie, a działania podejmowane przez Konrada II wobec Mieszka II w znaczącej mierze określało dążenie do zmuszenia polskich władców do rezygnacji z godności królewskiej³ ${ }^{3}$ W 1031 roku starszemu bratu Mieszka, Bezprymowi, udało się dzięki wsparciu udzielonemu mu przez cesarza i książąt ruskich odsunąć go od władzy i przejąć rządy nad Polską. Nowy władca pragnąc pozyskać przychylność Konrada, nie tylko nie zdecydował się na dopełnienie ceremonii koronacji, ale również postanowił przesłać mu na dowód porzucenia królewskich pretensji swojego ojca i brata insygnia wygnanego przez siebie Mieszka4 . Rok później także sam Mieszko, któremu udało się po śmierci Bezpryma odzyskać władzę, zabiegając o porozumienie z Konradem, zmuszony został nie tylko do ukorzenia się przed nim, lecz również do zrzeczenia się tytułu królewskiego 5 .

Trudno przesądzać jednoznacznie o przyczynach wrogości dworu cesarskiego wobec piastowskich koronacji. W informujących o nich źródłach mowa jest jedynie o pysze i zuchwalstwie polskich władców, sięgających po koronę wbrew cesarskiemu majestatowi $^{6}$. Kwestię negatywnej reakcji Konrada II na królewskie wywyższenie Piastów zwykło się jednak najczęściej rozpatrywać w kategoriach dążenia cesarza do podporządkowania sobie monarchii piastowskiej, a w królewskich aspiracjach Piastów widzieć świadectwo ich politycznych ambicji, zmierzających do pełnego uniezależnienia się spod cesarskiej zwierzchności. W gruncie rzeczy jednak nie ma wyraźnych świadectw, które wskazywałyby, że Piastowie kwestionowali ustanowiony przez władców ottońskich porządek i negowali ich dominującą pozycję w Europie Środkowej. Wieloletni spór Bolesława Chrobrego z Henrykiem II rozpatrywać należy bowiem nie tyle w kategoriach walki o uwolnienie się spod zależności wobec Rzeszy, ile raczej starań o wywalczenie sobie lepszej pozycji w jej ramach ${ }^{7}$. Nie wydaje się nawet, aby jego koronacja miała służyć zerwa-

3 Zob. np. Anatol LEWICKI, Mieszko II, w: Rozprawy Akademii Umiejętności, Wydział Historyczno-Filozoficzny 5 (1876), s. 87-208; Aniela POSPIESZYŃSKA, Mieszko II a Niemcy, w: Roczniki Historyczne 14 (1938), s. 239-295; Henryk ŁOWMIAŃSKI, Poczatki Polski: polityczne i społeczne procesy kształtowania się narodu do poczatku wieku XIV, t. 6, cz. 1. Warszawa 1985, s. 59; Gerard LABUDA, Mieszko II król Polski (1025-1034): czasy przełomu w dziejach państwa polskiego. Kraków 1992, s. 78 nn.; Błażej ŚLIWIŃSKI, Bezprym: pierworodny syn pierwszego króla Polski (986 - zima/wiosna 1032). Kraków 2014, s. 154 nn.

4 Annales Hildesheimenses wyd. Georg WAITZ (MGH Scriptores rerum Germanicarum in usum scholarum separatim editi. Vol. 8). Hannover 1878, s. 36: „Sed idem Bezbrimo imperatori coronam cum aliis regalibus, quae sibi frater eius iniuste usurpaverat, transmisit ac semet humili mandamine per legatos suos imperatori subditurum promisit."

5 Annales Hildesheimenses, s. 37: „Et postmodum imperatore consentiente Merseburg venit et semet Non. Iulii in imperatoriam potestatem, coronae scilicet ac tocius regalis ornamenti oblitus, humiliter dedit."

6 Zob. też Annales Hildesheimenses, s. 35.

7 Zob. np. Kurt GÖRICH, Eine Wende im Osten: Heinrich II. und Boleslaw Chrobry, w: Otto III. Heinrich II.: eine Wende?, red. Bernd Schneidmüller - Stefan Weinfurter. Sigmaringen 1997, s. 95-167; Stefan WEINFURTER, Kaiser Heinrich II. und Bolesław Chrobry: Herrscher mit ähnlichen Konzepten?, w: Questiones Medii Aevi Novae 9 (2004), s. 5-25. 
niu więzi łączących go z Rzeszą. Można nawet zaryzykować przypuszczenie, iż w zamyśle piastowskiego władcy miała ona prowadzić do mocniejszemu wpisaniu jego władzy w jej struktury ideowe.

W tym kontekście uwagę zwraca zwłaszcza miejsce, jakie wśród insygniów władzy pierwszych piastowskich władców przypadło włóczni św. Maurycego. Zgodnie z przekazem kroniki Galla Anonima włócznię tę wraz z przymocowaną do niej relikwią gwoździa z Krzyża Świętego Bolesław Chrobry miał otrzymać od Ottona III podczas spotkania obu monarchów w Gnieźnie w roku $1000^{8}$. Późna, powstała w drugim dziesięcioleciu XII wieku relacja kronikarska poświęcona przebiegowi zjazdu gnieźnieńskiego w wielu szczegółach może budzić zastrzeżenia. Nie brak zatem prób podawania w wątpliwość także jej informacji o przekazaniu Bolesławowi przez Ottona włóczni św. Maurycego ${ }^{9}$. Wydaje się jednak, że brak wystarczających podstaw do podważania wiarygodności przekazu Galla w tym zakresie i z dużą dozą pewności można łączyć włócznię, która do dzisiaj przechowywana jest w skarbcu katedry krakowskiej z opisanymi przez niego wydarzeniami ${ }^{10}$.

W ofiarowanej Bolesławowi przez Ottona III włóczni widzieć należy z pewnością replikę Świętej Włóczni, którą różne wątki tradycji łączyły nie tylko ze św. Maurycym, lecz również z włócznią, którą przebito bok Chrystusa na krzyżu i Konstantynem Wielkim. Wraz z przymocowanym do niej gwoździem z Krzyża Świętego stanowiła ona nie tylko cenną relikwię, ale w X i początkach XI wieku zyskała rangę jednego z najważniejszych oznak władzy niemieckich monarchów. Święta Włócznia towarzyszyła królom niemieckim w wyprawach wojennych, zapewniając im - jak wierzono - odniesienie zwycięstwa oraz podczas ceremonialnych wystąpień, zaświadczając o ich sprawowanej w imieniu Boga monarszej władzy ${ }^{11}$.

Wydaje się, że podobne treści z otrzymaną w Gnieźnie repliką Świętej Włóczni wiązali także władcy piastowscy. W najpełniejszy sposób znalazły one przedstawienie w przywołanej już relacji Galla Anonima, w której pobrzmiewa przechowywana na dworze piastowskim pamięć o królewskim charakterze cesarskiego daru. W przedstawieniu kro-

8 Galli Anonymi Cronicae et gesta ducum sive principum Polonorum (Monumenta Poloniae Historica. Nova Series. Vol. 2), wyd. Karol MALECZYNSKI. Kraków 1952, s. 19 (I 6).

9 Zob. Przemysław WISZEWSKI, Domus Bolezlai: Values and Social Identity in Dynastic Traditions of Medieval Poland (c. 966-1138). Leiden/Boston 2010, s. 411-415; Dariusz Andrzej SIKORSKI, Kościót w Polsce za Mieszka I i Bolesława Chrobrego: rozważania nad granicami poznania historycznego. Poznań 2011, s. 29 n.

10 Zob. Mieczysław ROKOSZ, Wawelska włócznia Bolesława Chrobrego: przegląd problematyki, w: Rocznik Krakowski 15 (1989), s. 17-44; Zbigniew DALEWSKI, Die Heilige Lanze und die polnischen Insignien, w: Europas Mitte um 1000: Beiträge zur Geschichte, Kunst und Archäologie. T. 2, red. Alfried Wieczorek - Hans-Martin Hinz. Stuttgart 2000, s. 907-911.

11 Zob. np. Adolf HOFMEISTER, Die heilige Lanze, ein Abzeichen des alten Reiches. Breslau 1908; HansWalther KLEWITZ, Die heilige Lanze Heinrichs I., w: Deutsches Archiv für Geschichte des Mittelalters 6 (1943), s. 42-58; Percy Ernst SCHRAMM, Die 'Heilige Lanze', Reliquie und Herrschaftszeichen des Reiches und ihre Replik in Krakau: ein Überblick über die Geschichte der Königslanze, w: Idem., Herrschaftszeichen und Staatssymbolik: Beiträge zu ihrer Geschichte vom dritten bis zum sechszehnten Jahrhundert. Stuttgart 1955, s. 492-537; Gunther WOLF, Heilige Lanze: Longinus-, Kreuznagel- oder Mauritius-Lanze, w: Idem., Satura mediaevalis: gesammelte Schriften herausgegeben zum 65. Geburtstag. T. 2: Ottonenzeit. Heidelberg 1995, s. 485-503; Mechthild SCHULZE-DÖRRLAMM, Die Heilige Lanze in Wien: die Frühgeschichte des karolingisch-ottonisch Herrschaftszeichens aus archäologischer Sicht, w: Jahrbuch des Römisch-Germanischen Zentralmuseums 58 (2011), s. 707-742; Karen BLOUGH, The Lance of St Maurice as a Component the Early Ottonian Campaign against Paganism, w: Early Medieval Europe 24 (2016), s. 338-361. 
nikarza ceremonia wręczenia włóczni św. Maurycego dopełnia bowiem dokonaną przez cesarza podczas spotkania w Gnieźnie koronację Bolesława, a sama włócznia, obok nałożonej mu na głowę przez Ottona korony, pełni rolę głównej oznaki nowej królewskiej godności polskiego władcy ${ }^{12}$. Na insygnialny charakter piastowskiej włóczni wskazują także słowa Brunona z Kwerfurtu, zawarte w jego liście skierowanym do Henryka II. Ganiąc króla za zawarcie wymierzonego przeciw Bolesławowi sojuszu z pogańskimi Lucicami, Brunon przeciwstawia bowiem czczonego przez nich Swarożyca św. Maurycemu oraz Świętą Włócznię diabelskim chorągwiom w sposób, który może sugerować, że łączył św. Maurycego i jego włócznię nie tylko z niemieckim królem, lecz również z władcą piastowskim $^{13}$. Pozłacana włócznia, obok korony, pojawia się również w roli głównej oznaki władzy zaświadczającej o królewskich pretensjach Mieszka II w przekazie roczników magdeburskich ${ }^{14}$.

Zapewne, na przyznanie otrzymanej od Ottona III replice Świętej Włóczni roli jednego z głównych insygniów władzy pierwszych Piastów niemały wpływ miały łączone z nią treści natury religijnej. Podarowana Bolesławowi włócznia prawdopodobnie bowiem zawierała w sobie zarówno fragmenty samej Świętej Włóczni, jak i umieszczonego w niej gwoździa z Krzyża Świętego. Tym samym miała również bez wątpienia udział w przynależnej jej wzorowi świętości. Można przypuszczać zatem, że odwołując się do posiadanej przez siebie kopii Świętej Włóczni władcy piastowscy dawali wyraz swojemu przekonaniu, iż również oni mają dostęp do łączonych z jej oryginałem mocy sakralnych i mogą liczyć na urzeczywistnianą za jej pośrednictwem Bożą opiekę ${ }^{15}$. Jednak nie mniej istotne, jak wolno sądzić, zwłaszcza w odniesieniu do królewskich aspiracji Piastów, było miejsce, jakie pierwowzorowi posiadanej przez nich włóczni przypadało w działaniach służących stanowieniu władzy królów niemieckich.

W 1002 roku Święta Włócznia odegrała bowiem niezwykle istotną rolę podczas wydarzeń, związanych z przejęciem władzy w Rzeszy po śmierci Ottona III przez Henryka II ${ }^{16}$. Zabiegając wówczas o tron i pragnąc dowieść legalności swoich pretensji do sukcesji po Ottonie, Henryk nie zawahał się uwięzić arcybiskupa Kolonii Heriberta, aby wymóc na nim oddanie mu ukrytej przez niego Świętej Włóczni ${ }^{17}$. Została ona następnie podczas mogunckiej koronacji uroczyście wręczona Henrykowi na dowód przejęcia przez niego królewskiej władzy, pomimo że w znanych wczesnośredniowiecznych ordines koronacyj-

12 Galli Anonymi Cronicae, s. 19 (I 6).

13 Epistola Brunonis ad Henricum regem (Monumenta Poloniae Historica. Nova Series. Vol. 4, cz. 3), wyd. Jadwiga KARWASIŃSKA. Warszawa 1973, s. 101 n.; por. jednak WISZEWSKI, Domus Bolezlai, s. 414 .

14 Annales Magdeburgenses, wyd. Georg Heinrich Pertz u. a., in: MGH Scriptores (in Folio). Vol. 16: Historiae aevi Suevici. Hannover 1859, s. 170.

15 Por. Jerzy BANASZKIEWICZ, Otton III jedzie do Gniezna: o oprawie ceremonialnej wizyty cesarza w kraju i stolicy Polan, w: Idem, Trzy po trzy o dziesiątym wieku. Kraków 2014, s. 197 nn.

16 Zob. Reinhard SCHNEIDER, Die Königserhebung Heinrich II. im Jahre 1002, w: Deutsches Archiv für Erforschung des Mittelalters 28 (1972), s. 74-104; Walther SCHLESINGER, Erbfolge und Wahl bei der Königserhebung Heinrichs II. 1002, w: Festschrift für Hermann Heimpel zum 70. Geburtstag. T. 3. Göttingen 1972, s. 1-36; Stefan WEINFURTER, Der Anspruch Heinrichs II. auf die Königsherrschaft, w: Papstgeschichte und Landesgeschichte: Festschrift für Hermann Jakobs zum 65. Geburtstag, red. Joachim Dahlhaus - Armin Kohnle. Köln/Weimar/Wien 1995, s. 121-134; Idem, Heinrich II. (1002-1024): Herrscher am Ende der Zeiten. Regensburg 2002, s. 36 nn.

17 Thietmari Merseburgensis episcopi Chronicon (MGH Scriptores rerum Germanicarum. Nova series. Vol. 9), wyd. Robert HOLTZMANN. Berlin 1935, s. 188 (IV 50). 
nych nie wspomina się o niej ${ }^{18}$. Kilka miesięcy później na zjeździe w Merseburgu Święta Włócznia ponownie wystąpiła w roli insygnium nie tylko zaświadczającego o monarszych prawach Henryka, lecz wprost wprowadzającego go w nie: zgoda możnych saskich na podporządkowanie się zwierzchności nowego króla znalazła wówczas ponownie swoje ceremonialne uzewnętrznienie w akcie przekazania mu Świętej Włóczni, tym razem przez księcia saskiego Bernarda ${ }^{19}$.

W wydarzeniach rozgrywających się w Merseburgu wziął udział także Bolesław Chrobry ${ }^{20}$. Mógł zatem naocznie przekonać się o znaczeniu wartości przypisywanych Świętej Włóczni i roli, jaka przypadała jej w procesie legitymizacji władzy królów niemieckich. Niewykluczone zatem, że sięgając samemu blisko ćwierć wieku później po koronę zdecydował się na wykorzystanie posiadanej przez siebie jej kopii do przeprowadzenia własnej koronacji. Nie wydaje się jednak, aby chodziło w tym przypadku wyłącznie o proste naśladownictwo niemieckich wzorów ceremonialnych, do którego mogło go zachęcić dodatkowo prawdopodobne posłużenie się Świętą Włócznią także podczas niedawno przeprowadzonej w Moguncji w 1024 roku koronacji następcy Henryka II, Konrada II ${ }^{21}$. Można sądzić, iż w zamyśle Bolesława otrzymana przez niego od Ottona III włócznia św. Maurycego miała służyć także, a może nawet przede wszystkim, legitymizacji jego królewskich aspiracji i prowadzić do wpisania jego nowo uzyskanej godności królewskiej w struktury polityczne i ideowe Rzeszy. Nie wiemy, jakie treści w zamyśle Ottona III miały łączyć się z ceremonią wręczenia Bolesławowi w Gnieźnie repliki Świętej Włóczni. Postanowienia zjazdu gnieźnieńskiego budzą, jak wiadomo, liczne kontrowersje ${ }^{22}$. Nie ma potrzeby w tym miejscu wchodzenia w szczegóły toczonych wokół tych zagadnień dyskusji. Nie ulega jednak wątpliwości, że gnieźnieńskie wydarzenia w zasadniczy sposób zmieniały status polskiego władcy, wynosząc go, jak obrazowało ujął to Thietmar z Merseburga, $\mathrm{z}$ pozycji trybutariusza do rangi pana ${ }^{23}$, a istotną rolę w tym awansie Bolesława, zaświadczając jednocześnie o nim, odgrywać miała z pewnością podarowana mu przez Ottona włócznia św. Maurycego. Niewykluczone zatem, że również podczas koronacji w 1025 roku Bolesław odwołał się do niej i zdecydował się na włączenie ceremonii jej wręczenia w ramy uroczystości swojej sakry. Wykorzystanie włóczni św. Maurycego w jej trakcie w charakterze królewskiego insygnium - przypomnijmy, wbrew liturgicznej tradycji - można by tłumaczyć dążeniem Bolesława do zaznaczenia związków swojej koronacji z decyzjami podjętymi na zjeździe gnieźnieńskim i zademonstrowania w niebudzący wątpliwości sposób, że sięgając po królewską koronę nie występuje przeciw cesarzowi, lecz jedynie realizuje przyznane mu już przed laty w Gnieźnie uprawnienia.

Wydaje się jednak, że z działaniami Bolesława zmierzającymi do wykorzystania insygnium, którym posługiwali się władcy ottońscy, do zamanifestowania własnych aspiracji

18 Thangmari Vita Berwardi Episcopi Hildesheimensis, wyd. Georg Heinrich PERTZ, w: MGH Scriptores (in Folio). Vol. 4: Annales, chronica et historiae aevi Carolini et Saxonici. Hannover 1846, s. 775 (IV 38).

19 Thietmari Chronicon, s. 239-241 (V 16-17).

20 Thietmari Chronicon, s. 239 (V 15); s. 241 (V 18).

21 Ademari Cabannensis Chronicon, wyd. Pascale BOURGAIN, w: Corpus Christianorum. Continuatio Mediaevalis. Vol. 129. Turnhout 1999, s. 183, wersja $\gamma$ (III 62).

22 Zob. np. Jerzy STRZELCZYK, Zjazd gnieźnieński. Wrocław 2000.

23 Thietmari Chronicon, s. 232 (V 10); Edward SKIBIŃSKI, Koronacje pierwszych Piastów w najstarszych źródłach narracyjnych, w: Gnieźnieńskie koronacje królewskie i ich środkowoeuropejskie konteksty, red. Józef Dobosz - Marzena Matla - Leszek Wetesko. Gniezno 2011, s. 216 nn. 
królewskich łączyły inne jeszcze istotne znaczenia, dotykające samej istoty instytucji królewskiej. W tym kontekście szczególną uwagę zwraca skierowany do Mieszka II list dołączony do ofiarowanej mu przez Matyldę Szwabską, zapewne wkrótce po jego koronacji w 1025 roku, księgi obrzędów ${ }^{24}$. Wśród nielicznych przekazów źródłowych odnoszących się do królewskiej godności pierwszych Piastów tekst ten zajmuje miejsce wyjątkowe. W jego przypadku mamy bowiem do czynienia z jedynym w swoim rodzaju, odnoszącym się bezpośrednio do władcy piastowskiego, wykładem dotyczącym zagadnienia natury władzy królewskiej, charakteru przysługujących królowi praw i rodzaju spoczywających na nim obowiązków ${ }^{25}$.

Zwracając się do Mieszka, redaktor listu wprost wskazał, że został on wyniesiony na tron przez Boga: to łaska Boża nadała mu zarówno królewskie imię, jak i dostojeństwo, nie ludzkim, lecz Boskim wyrokiem otrzymał on królewskie rządy i z ustanowienia Boga został ukoronowany królewskim diademem. Przedstawiając zaś jego panowanie podkreślił, że Mieszko sprawował swoje rządy z rozwagą, otaczał opieką wdowy, sieroty oraz ubogich. Jednocześnie jednak wydając wyroki nie brał pod uwagę ani pozycji społecznej, ani majątku, lecz kierował się zasadami sprawiedliwości ${ }^{26}$. Niemniej w ujęciu redaktora listu troska o potrzebujących i sprawiedliwość w wyrokowaniu w żadnym razie nie wyczerpywały zalet Mieszka jako władcy. W gruncie rzeczy nie znajdowały się one nawet w centrum jego zainteresowań. $Z$ pewnością, urzeczywistniały się w nich monarsze przymioty polskiego władcy i w istotnej mierze określały one jego królewską pozycję. Można odnieść jednak wrażenie, że stanowiły one jedynie dopełnienie, czy też może konsekwencję innych podejmowanych przez niego działań. Warto bowiem zwrócić uwagę, że swoją prezentację rządów Mieszka redaktor listu rozpoczął od stwierdzenia, że poświęcił on Bogu pierwociny swojego królestwa i nie omieszkał też wspomnieć o wzniesieniu przez niego licznych kościołów oraz chwaleniu Boga nie tylko po łacinie i we własnym języku, lecz również po grecku. Nie zawahał się także nazwać go najbardziej błogosławionym i podkreślił, że obraca się w kręgu spraw niebiańskich. Nie szczędził też słów pochwały dla podejmowanych przez Mieszka starań o prowadzenie ku Bogu - jak to ujął - dusz uwiedzionych diabelskim podstępem ${ }^{27}$. Z listu Matyldy zdaje się zatem wynikać, iż w przeświadczeniu jego redaktora królewska władza Mieszka II miała przede wszystkim charakter religijnego posłannictwa, a jej zakres wykraczał znacznie poza sprawy doczesne. Powołany przez Boga do sprawowania królewskich rządów piastowski władca miał w pierwszej kolejności troszczyć się o zbawienie powierzonego jego zwierzchności ludu.

W liście nie wskazuje się wprost, w jaki sposób Mieszko miał realizować tak określone zadania. Pewnych wskazówek w tym względzie wydaje się jednak dostarczać już sam jego kontekst. List, jak już wspomniano, dołączony został do ofiarowanej przez Matyl-

${ }^{24}$ Epistola Mathildis Suevae, wyd. Brygida KÜRBIS, w: Codex Mathildis. Liber officiorum cum foliis dedicationis (Monumenta Sacra Polonorum. Vol. 1). Kraków 2000, s. 139 n.

25 Zob. np. Brygida KÜRBIS, Die Epistola Mathildis Suevae an Mieszko II. in neuer Sicht: ein Forschungsbericht, w: Frühmittelalterliche Studien 23 (1989), s. 318-338; Eadem, Epistola Mathildis Suevae, w: Codex Mathildis, s. 49-83; Roman MICHAŁOWSKI, Princeps fundator: studium $z$ dziejów kultury politycznej w Polsce X-XIII wieku. Warszawa 1989, s. 85-119; Andrzej PLESZCZYŃSKI, The Birth of Stereotype: Polish Rulers and their Country in German Writings c. 1000 A.D. Leiden/Boston 2011, s. 254-274; WISZEWSKI, Domus Bolezlai, s. 66-76.

26 Epistola Mathildis Suevae, s. 139 n.

27 Epistola Mathildis Suevae, s. 139. 
dę Mieszkowi księgi obrzędów, zawierającej objaśnienia świąt roku liturgicznego oraz porządku sprawowania obrzędów mszy i sakramentów ${ }^{28}$. Nie ulega wątpliwości, że do spisania interesującego nas kodeksu doszło na zamówienie Matyldy i powstał on z myślą o przekazaniu go Mieszkowi ${ }^{29}$. Wybór jako daru dla polskiego władcy właśnie księgi, przynoszącej informacje o właściwym przebiegu obrzędów kościelnych i wyjaśniającej teologiczny sens składających się na nie rytów, wynikał zatem ze świadomej decyzji, znajdującej najpewniej uzasadnienie w przekonaniu, iż stanowi ona odpowiedni podarunek dla wyróżnionego królewską godnością odbiorcy. W dołączonym do księgi liście wyłożono zresztą wprost racje, jakimi kierowała się Matylda, polecając przygotowanie dla Mieszka dzieła wyjaśniającego, w jaki sposób należy celebrować liturgiczne obrzędy, wskazując, że postanowiła ona przesłać je polskiemu władcy po to, aby nic, co dotyczy służby Bożej, nie pozostawało mu nieznane ${ }^{30}$.

Trudno nie łączyć wyrażonego w liście pragnienia pogłębienia przez Mieszka znajomości liturgii z opisanymi w nim wcześniej jego wielkimi dokonaniami i podejmowanymi przez niego wysiłkami zmierzającymi do zapewnienie poddanym zbawienia. Redaktor listu zdaje się bowiem niedwuznacznie sugerować, że droga do wypełnienia religijnych w swej naturze zadań, postawionych przez Boga przed powołanym przez Niego do pełnienia godności królewskiej władcą, wiedzie przez liturgię, a głównym obowiązkiem króla powinna być troska o jej właściwe sprawowanie. Można nawet odnieść wrażenie, że w jego przedstawieniu Bóg wyniósł Mieszka do królewskiej władzy przede wszystkim po to, aby ten zatroszczył się o to, aby służba Boża była sprawowana w odpowiedni sposób.

Wymieniając liczne zalety piastowskiego władcy, redaktor listu zaznaczył również, że został on wyposażony w duchowe uprzywilejowanie - spiritali prerogatiua ${ }^{31}$. Nie jest w pełni jasne, jakie treści miały łączyć się z tym sformułowaniem. Z kontekstu, w jakim się ono pojawia, zdaje się jednak niedwuznacznie wynikać, iż będące udziałem Mieszka duchowe uprzywilejowanie dawało mu prawo do zawiadywania sprawami odnoszącymi się do kwestii liturgicznych i wynikało bezpośrednio z faktu sprawowania przez niego królewskiej władzy. W liście brak bezpośrednich odwołań do ceremonii królewskiej sakry. Nie sposób jednak nie łączyć wspomnianego przez jego redaktora mającego wyróżniać Mieszka duchowego uprzywilejowania właśnie z rytem namaszczenia. W składających się na liturgiczną uroczystość królewskiego wyniesienia rytualnych gestach i towarzyszących im modlitewnych oracjach, sytuujących namaszczanego na wzór Chrystusa władcę w sferze sakralnej i rozciągających zakres jego władzy daleko poza sprawy doczesne ${ }^{32}$, mogła bowiem znaleźć najpełniejsze uzasadnienie uwypuklona w li-

28 Liber officiorum, wyd. KÜRBIS, w: Codex Mathildis, s. 147-273.

29 Epistola Mathildis Suevae, s. 52.

30 Epistola Mathildis Suevae, s. 140: „Hunc autem librum ideo tibi direxit, ne quid in diuinis officis incognitum foret tuae regiae dignitatis ...”

31 Epistola Mathildis Suevae, s. 140.

32 Zob. np. Percy Ernst SCHRAMM, Der Ablauf der deutschen Königsweihe nach dem 'Mainzer Ordo' (um 960), w: Idem, Kaiser, Könige und Päpste: gesammelte Aufsätze zur Geschichte des Mittelalters. T. 3. Stuttgart 1969, s. 59-107; Cornelius Adrianus BOUMAN, Sacring and Crowning: the Development of the Latin Ritual for the Anointing of Kings and the Coronation of an Emperor before the Eleventh Century. Groningen/Djakarta 1957, s. 90 nn; Robert DESHMAN, Christus rex et magi reges: Kingship and Christology in Ottonian and Anglo-Saxon Art, w: Frühmittelalterliche Studien 10 (1976), s. 367-406; Rudolf SCHIEFFER, Mediator cleri et plebis: zum geistlichen Einfluß auf Verständnis und Darstellung des ottonischen Königtums, w: Herrschaftsrepräsentation im ottonischen Sachsen, red. Gerd Althoff - 
ście szczególna pozycja Mieszka jako władcy, który - żeby odwołać się raz jeszcze do słów jego redaktora - obraca się w kręgu spraw niebieskich.

Trudno jednoznacznie rozstrzygać, w jakim stopniu w utrwalonym w liście Matyldy obrazie Mieszka II, skupiającego się na wypełnianiu religijnych przede wszystkim obowiązków, pobrzmiewa echo idei kultywowanych na dworze piastowskim, a w jakiej mierze odwoływał się jedynie do wyobrażeń właściwych kulturze politycznej Rzeszy. Fundatorka przeznaczonego dla Mieszka kodeksu, Matylda Szwabska, była matką kontrkandydata Konrada II w zabiegach o przejęcie tronu po śmierci Henryka II w 1024 roku, Konrada Młodszego. Popierający go możni, wśród których ważną rolę ogrywali panowie lotaryńscy, w tym drugi mąż Matyldy, książę Górnej Lotaryngii Fryderyk II, nie od razu chcieli pogodzić się z wyborem Konrada II. Ostatecznie dopiero w 1027 roku nowemu królowi udało się złamać opór opozycji i uzyskać powszechne uznanie ${ }^{33}$. Z tymi wydarzeniami zwykło się też przeważnie łączyć powstanie kodeksu Matyldy, widząc w nim świadectwo podjęcia przez kręgi niechętne Konradowi II starań o nawiązanie kontaktów z polskim władcą, a nawet być może pozyskania jego poparcia do działań przeciw nowemu królowi ${ }^{34}$.

Bez wątpienia, Matylda i redaktor dołączonego do zamówionego przez nią kodeksu listu musieli w pełni zdawać sobie sprawę z negatywnych reakcji, jakie piastowskie koronacje wywołały w różnych kręgach politycznych w Rzeszy i podnoszonych przez dwór cesarski wątpliwości dotyczących ich prawomocności. W tej sytuacji w ofiarowanym mu wspaniałym darze widzieć by można swoistą manifestację ze strony Matyldy i związanych z nią środowisk uznania dla kwestionowanego przez Konrada II królewskiego tytułu polskiego władcy. Niewykluczone zatem, że zawarta w liście dołączonym do przekazanej mu księgi obrzędów pochwała jego królewskich rządów, dowodząca, że godzien on jest sprawowania królewskiej godności, nawiązywała w pierwszym rzędzie nie tyle do programów ideowych rozwijanych w jego otoczeniu, co raczej do koncepcji władzy królewskiej podzielanych w przez kręgi związane z fundatorką kodeksu. Odnajdujemy w niej bowiem podstawowe elementy rozwijanych w czasach ottońskich idei, określających sposoby postrzegania instytucji królewskiej, które sytuowały wyniesionego na tron władcę w sferze sakralnej i ujmowały sprawowaną przez niego władzę przede wszystkim w kategoriach religijnego posłannictwa ${ }^{35}$. Wyłaniający się z listu Matyldy obraz Mieszka w pełni wpi-

Ernst Schubert. Sigmaringen 1998, s. 344-361; Giovanni ISABELLA, Das Sakralkönigtum in Quellen aus ottonischer Zeit: unmittelbarer Bezug zu Gott oder Vermittlung durch die Bischöfe, w: Frühmittelalterliche Studien 44 (2011), s. 137-152.

33 Zob. Franz-Reiner ERKENS, Konrad II. (um 990-1039): Herrschaft und Reich des ersten Salierkaisers. Regensburg 1998, s. 13 nn.; Herwig WOLFRAM, Konrad II. 990-1039: Kaiser dreier Reiche. München 2000, s. $60 \mathrm{nn}$.

34 Zob. LABUDA, Mieszko II król Polski s. 63 nn.

35 Zob. np. Stefan WEINFURTER, Idee und Funktion des 'Sakralkönigtums' bei den ottonischen und salischen Herrschern (10. und 11. Jahrhundert), w: Legitimation und Funktion des Herrschers: vom ägyptischen Pharao zum neuzeitlichen Diktator, red. Rolf Gundlach - Hermann Weber. Stuttgart 1992, s. 99-127; Idem, Zur 'Funktion' des ottonischen und salischen Königtums, w: Mittelalterforschung nach der Wende, red. Michael Borgolte. München 1995, s. 249-361; Egon BOSHOF, Die Vorstellung vom sakralen Königtum in karolingisch-ottonischer Zeit, w: Das frühmittelalterliche Königtum: ideelle und religiöse Grundlagen, red. Franz-Reiner Erkens. Berlin/New York 2005, s. 331-358; Franz-Reiner ERKENS, Herrschersakralität im Mittelalter: von den Anfängen bis zum Investiturstreit. Stuttgart 2006, s. 157 nn.; Ludger KÖRNTGEN, Königsherrschaft und Gottes Gnade: zu Kontext und Funktion sakraler Vorstellungen in Historiographie und Bildzeugnissen der ottonisch-frühsalischen Zeit. Berlin 2001. 
suje się w ramy ottońskiego modelu władcy, który dzierżąc władzę z Boskiego nadania, kieruje się w swoich rządach Bożymi przykazaniami, czuwa nad przestrzeganiem sprawiedliwości i zabiega o pomyślność poddanych, a przede wszystkim, troszczy się o ich życie wieczne ${ }^{36}$.

Nie wydaje się jednak, aby przedstawiony w liście opis rządów Mieszka II można było rzeczywiście sprowadzać wyłącznie do odniesienia przez jego redaktora do polskiego władcy właściwych kulturze politycznej Rzeszy koncepcji monarszej władcy. Można sądzić raczej, że w liście znalazły odzwierciedlenie także opinie, jakie na temat charakteru sprawowanej przez Mieszka zwierzchności formułowane były w jego najbliższym otoczeniu, a w przedstawionej w nim charakterystyce jego rządów doszukiwać się można śladów propagowanego przez Piastów wizerunku ich władzy.

O przebiegu koronacji pierwszych Piastów praktycznie nic nie wiemy. Nie ulega jednak wątpliwości, że także w ich przypadku uroczystości przekazania im królewskiej władzy musiały znaleźć swoje rytualne uzewnętrznienie w akcie namaszczenia, a wypowiadane w ich trakcie modlitwy musiały jednoznacznie wskazywać na wiązane z tytułem królewskim zadania w sferze religijnej. Trudno też wątpić w to, iż władcy piastowscy w pełni zdawali sobie sprawę ze znaczeń łączących się z ich królewskim wyniesieniem.

Przeprowadzone w 1025 roku koronacje Bolesława Chrobrego i Mieszka II stanowiły zwieńczenie podejmowanych przez tego pierwszego przez wiele lat starań o uzyskanie królewskiej korony. Już w początkach XI wieku, przypuszczalnie w 1003 roku, miał Bolesław zabiegać w Rzymie o uzyskanie zgody papieża na swoją koronację ${ }^{37}$. Z planami koronacyjnymi można też zapewne wiązać bite przez niego denary z napisem REX BOLIZLAVUS, których emisję kładzie się na lata 1005-1015 ${ }^{38}$. Z pewnością, za królewskimi dążeniami piastowskiego władcy stały złożone motywy. Nie bez znaczenia były w tym względzie także racje natury politycznej, związane najpewniej z zamysłami zmiany dotychczasowego modelu sukcesji tronu, prowadzącymi do zerwania z tradycją postrzegania władzy w kategoriach własności całej dynastii i skupienia władzy w rękach jej jednego wyróżnionego królewską koroną przedstawiciela ${ }^{39}$. Niemniej ponawiane uporczywie przez Bolesława przez blisko ćwierć wieku wysiłki o zdobycie korony w niemniejszej mierze, a może nawet przede wszystkim, określało także dążenie do wpisania sprawowanej przez niego władzy w złożony kompleks wyobrażeń i idei, jakie w dobrze mu znanej tradycji politycznej Rzeszy łączono z godnością królewską, sytuujących wyróżnionego namaszczeniem władcę w sferze sakralnej i przyznających jego władzy religijny w istocie charakter. Nie brak bowiem danych, które pozwalają sądzić, iż Bolesław jeszcze przed swoją koronacją postrzegał sprawowaną przez siebie władzę w kategoriach sakralnych

36 Zob. Zbigniew DALEWSKI, Sakralność władzy królewskiej pierwszych Piastów, in: Historia Slavorum Occidentis 14 (2017), s. 43-57.

37 Petri Damiani Vita beati Romualdi (Fonti per la storia d'Italia. Vol. 94), wyd. Giovanni TABACCO. Roma 1957, s. 62 (Kap. 28).

38 Zob. Stanisław SUCHODOLSKI, Rex Bolizlavus: tzw. królewskie monety Bolesława Chrobrego, w: Heraldyka i okolice, red. Andrzej Rachuba - Sławomir Górzyński - Halina Manikowska. Warszawa 2002, s. 285-295.

39 Zbigniew DALEWSKI, Modele władzy dynastycznej w Europie Środkowo-Wschodniej we wcześniejszym średniowieczu. Warszawa 2014, s. 95-184; Idem, Strategies of Creating Dynastic Identity in Central Europe in the 10th-11th Centuries, w: Imagined Communities: Constructing Collective Identities in Medieval Europe, red. Andrzej Pleszczynski - Joanna Aleksandra Sobiesiak - Michal Tomaszek Przemyslaw Tyszka. Leiden/Boston 2018, s. 30-45. 
i przykładał dużą wagę do działań, manifestujących przysługujące mu w jego przekonaniu uprawnienia w odniesieniu do zagadnień natury religijnej ${ }^{40}$.

Warto w tym miejscu jeszcze raz sięgnąć do listu Matyldy. Pojawia się w nim bowiem także postać Bolesława Chrobrego, chociaż nie zostaje on przywołany $\mathrm{z}$ imienia. Na szczególną uwagę zasługuje kontekst, w którym się o nim wspomina. Z listu dowiadujemy się, że ojciec Mieszka II był w tej części świata, którą władał źródłem i początkiem wiary katolickiej i siłą zmuszał dzikie i barbarzyńskie ludy, których nie mogły oczyścić słowa kaznodziejów, do przystąpienia do stołu Pańskiego ${ }^{41}$. W przekazanym przez Matyldę obrazie rządów Bolesława z pewnością pobrzmiewa echo tradycji przechowywanej na dworze piastowskim. Panowanie Bolesława znaczyły bowiem w istocie różnorodne prowadzone przy jego udziale przedsięwzięcia misyjne. W 997 r. udzielił poparcia misji św. Wojciecha do Prus. W następnych latach podjął najpewniej przygotowania do rozpoczęcia działań ewangelizacyjnych na Połabiu. Okazywał też pomoc przedsięwzięciom misyjnym Brunona z Kwerfurtu ${ }^{42}$. Zwrócenie przez redaktora listu Matyldy właśnie na ten aspekt działalności Bolesława Chrobrego, w pełni wpisujący się w funkcjonujący w czasach ottońskich model władzy królewskiej, w którym ważne miejsce przypadało kwestii szczególnej odpowiedzialności powołanego przez Boga władcy za podejmowanie wysiłków mających na celu nawrócenie pogan na chrześcijaństwo, nie pozostawia wątpliwości co do tego, że również władcy piastowscy postrzegali sprawowane przez siebie rządy przede wszystkim w kategoriach religijnego posłannictwa.

Do podobnych wniosków skłania także przekazana przez Thietmara z Merseburga informacja o represjach stosowanych przez Bolesława wobec winnych cudzołóstwa i spożywania mięsa w okresie Wielkiego Postu. Winnych tych wykroczeń w pierwszym przypadku karano kastracją, w drugim wyłamywano im zęby ${ }^{43}$. Okazywaną przez polskiego władcę troskę o przestrzeganie przez jego poddanych kościelnych przykazań łączyć najpewniej można z prowadzonymi przez niego szerzej zakrojonymi działaniami, mającymi analogie w podobnych przedsięwzięciach podejmowanymi przez władców innych świeżo chrystianizowanych wczesnośredniowiecznych monarchii środkowoeuropejskich, zmierzającymi do podporządkowania reguł życia społecznego normom religii chrześcijańskiej $^{44}$. Znajdowały one najpewniej uzasadnienie w mocno osadzonym w tradycji politycznej łacińskiego Zachodu we wcześniejszym średniowieczu przekonaniu o wyjątkowej

40 Por. Zbigniew DALEWSKI, The Public Dimension of Religion in the Piast Monarchy during the Christianisation Period, w: Acta Poloniae Historica 101 (2010), s. 37-49.

41 Epistola Mathildis Suevae, s. 139: „Paternis nempe exemplis ammonitus, totus pene uersaris in caelestibus, qui in illa mundi parte quam regis quasi quidam fons et origo sanctae catholicae et apostolice extitit fidei. Nam quos sancti praedicatores corrigere non poterant uerbo ille insecutus est ferro, compellens ad caenam dominicam barbaras ac ferocissimas nationes."

42 Zob. Roman MICHAŁOWSKI, The Gniezno Summit: the Religious Premises of the Founding of the Archbishopric of Gniezno. Leiden/Boston 2016, s. 187-206.

43 Thietmari Chronicon, s. 494 (VIII 2): „Si quis in hoc alienis abuti uxoribus vel sic fornicari presumit, hanc vindictae subsequentis poenam protinus senit. In pontem mercati is ductus per follem testiculi clavo affigitur et novacula prope posita hic moriendi sive de hiis absolvendi dura eleccio sibi datur. Et quicumque post LXX. carnem manducasse invenitur, abcisis dentibus graviter punitur."

${ }_{44}$ Zob. np. Roman MICHAŁOWSKI, Christianisation of the Piast Monarchy in the 10th and 11th Centuries, w: Acta Poloniae Historica 101 (2010), s. 14-32; Marcin Rafal PAUK, Washing Hands in a Sinner's Blood: Ducal Power, Law and Religious Zeal in the Process of Central European Christianization - Preliminary Remarks, w: Leben zwischen und mit den Kulturen: Studien zu Recht, Bildung und Herrschaft in Mitteleuropa, red. Renata Skowrońska - Helmut Flachenecker. Toruń 2015, s. 23 nn. 
odpowiedzialności władcy za właściwe wypełnianie przez jego poddanych religijnych powinności, określającej w istocie sens sprawowania przez nich królewskiej godności ${ }^{45}$. Za przypuszczeniem, że odnotowane przez Thietmara działania Bolesława Chrobrego wpisywały się również w ten kompleks wyobrażeń i wynikały z podzielanego przez niego przeświadczenia o religijnej naturze jego władzy przemawiają dodatkowe jeszcze okoliczności. Z relacji kronikarza wynika bowiem, iż zakaz spożywania mięsa swoim rygoryzmem wykraczał w monarchii Bolesława poza regulacje przewidziane w tym zakresie w prawie kanonicznym i dotyczył nie tylko Wielkiego Postu, lecz również poprzedzających go dwóch tygodni przedpościa. Podkreślone przez Thietmara zaangażowanie piastowskiego władcy w egzekwowanie zakazów związanych z wydłużonym Wielkim Postem pozwala sądzić, iż to właśnie on odegrał główną rolę w przyjęciu przez Kościół polski rozwiązań odbiegających w tym względzie od zasad obowiązujących w Kościele powszechnym, co z kolei nasuwa domysł, że nie tylko poczuwał się do odpowiedzialności za przestrzeganie przez jego poddanych Bożych przykazań, lecz również uważał się za uprawnionego do ingerowania w treść kościelnych przepisów i ich modyfikowania ${ }^{46}$.

Podobne treści łączyć także należy, jak można sądzić, z inną przekazaną przez Thietmara informacją, dotyczącą praktyk pokutnych podejmowanych przez Bolesława. Z jego relacji dowiadujemy się bowiem, że polski władca w przypadku popełnienia grzechu, kazał przedkładać sobie kanony, aby dowiedzieć się, w jaki sposób powinien naprawić swój grzeszny uczynek, a następnie zgodnie z zawartymi w nich wskazówkami czynił pokutę $^{47}$. Relacja kronikarza nie jest wprawdzie, o czym będzie jeszcze mowa, w pełni jednoznaczna. Niemniej wydaje się, że w przywołanym przez niego obrazie dopełniającego pokutę Bolesława dostrzec można czytelne odwołanie do mających liczne poświadczenia źródłowe praktyk pokutnych władców niemieckich wcześniejszego średniowiecza. Mocno osadzony w tradycji karolińskiej zwyczaj demonstrowania przez władcę w akcie publicznego ukorzenia jego pokory, humilitas, zyskał w epoce ottońskiej nowe treści. Dzięki odniesieniu do niego wyobrażeń łączonych z humilatio Chrystusa królewskie ukorzenie zaczęło nabierać jednoznacznie chrystomimetycznego charakteru: podobnie jak Chrystus cierpiąc na krzyżu zapewnił światu zbawienie, tak również namaszczony na Jego podobieństwo król, dopełniając pokutnych rytów, otwierał przed swoimi poddanymi szansę na życie wieczne ${ }^{48}$.

45 Zob. np. Janet Loughland NELSON, Kingship and empire, w: Carolingian Culture: Emulation and Innovation, red. Rosamond McKitterick. Cambridge 1994, s. 52-87.

46 Roman MICHAŁOWSKI, The Nine-Week Lent in Boleslaus the Brave's Poland: a Study of the First Piasts' Religious Policy, w: Acta Poloniae Historica 89 (2004), s. 5-50.

47 Thietmari Chronicon, s. 384 (VI 92): „Cum se multum pecasse aut ipse sentit aut aliqua fideli castigacione perpendit, canones coram se poni qualiterque id debeat emendari, ut queratur, precipit ac secundum haec scripta mox scelus peractum purgare contendit."

48 Zob. np. Lothar BORNSCHEUER, Miseriae regum: Untersuchungen zum Krisen- und Todesgedanken in den herrschaftstheologischen Vorstellungen der ottonisch-salischen Zeit. Berlin 1968, s. 131 nn.; Robert DESHMAN, The Exalted Servant: the Ruler Theology of the Prayerbook of Charles the Bald, w: Viator 11 (1980), s. 387-417; David A. WARNER, Henry II at Magdeburg: Kingship, Ritual and the Cult of Saints, w: Early Medieval Europe 3 (1994), s. 135-166; Klaus SCHREINER, Nudis pedibus: Barfüßigkeit als religiöses und politisches Ritual, w: Formen und Funktionen öffentlicher Kommunikation im Mittelalter, red. Gerd Althoff. Stuttgart 2001, s. 104 nn.; Gerd ALTHOFF, Die Macht der Rituale: Symbolik und Herrschaft im Mittelalter. Darmstadt 2003, s. 113 nn; Rob MEENS, Penance in Medieval Europe, 600-1200. Cambridge 2014, s. $181 \mathrm{nn}$. 
Rzecz jasna, nie wiemy, w jakiej mierze, jeśli w ogóle, chrystomimetyczne odniesienia mogły odcisnąć swój ślad na praktykach pokutnych Bolesława Chrobrego. Niezależnie jednak od wątpliwości w tej kwestii, wydaje się, że w przywołanym przekazie Thietmara widzieć można świadectwo znaczenia, jakie w rozwijanych w otoczeniu Bolesława Chrobrego programach ideowych przypadało kwestii monarszej pokory, rozumianej w kategoriach zrytualizowanego aktu publicznego ukorzenia, służącego pozyskaniu Bożej przychylności dla całej poddanej zwierzchności pokutującego władcy wspólnoty. Kronikarska relacja pozwala również, jak się wydaje, lepiej zrozumieć przyczyny, skłaniające Bolesława do wydłużenia okresu trwania Wielkiego Postu o dodatkowe dwa tygodnie. Można bowiem zastanawiać się, czy wydłużenia przez niego czasu obowiązywania wielkopostnych wyrzeczeń i umartwień nie należałoby wiązać właśnie z odnotowanymi przez Thietmara jego praktykami pokutnymi: monarchia, w której tak długo dopełniano związaną z Wielkim Postem pokutę, musiała być szczególnie miła Bogu, a jej władca wraz ze swoimi poddanymi mógł liczyć na Jego szczególną opiekę i wsparcie, a w rezultacie na zbawienie $^{49}$.

Wspominając o pokutnych praktykach Bolesława Chrobrego Thietmar nie ukrywa swojej niechęci do niego. Przyznaje, że polski władca w przypadku popełnienia grzechu przystępował do pokuty, wskazuje jednak przy tym, że sam określał jej rozmiar, a na dodatek nie potrafił w niej wytrwać ${ }^{50}$. Być może do przedstawionej przez Thietmara oceny pokutnych praktyk Bolesława nie powinno się przykładać zbyt dużej wagi i widzieć w niej należy jedynie kolejny przykład wielokrotnie demonstrowanego przez niego w kronice jego wrogiego stosunku do polskiego władcy ${ }^{51}$. Niewykluczone jednak, że w tym przypadku z krytyką zachowania Bolesława mogły się łączyć dodatkowe jeszcze znaczenia. Ryt publicznego monarszego ukorzenia niósł bowiem ze sobą jednoznaczne skojarzenia, dowodząc szczególnego charakteru relacji łączących dopełniającego go władcy z Bogiem i jego odpowiedzialności - w wymiarze eschatologicznym - za powierzony jego władzy lud Boży. W tym sensie był rytem w pełni tego słowa znaczeniu królewskim, po który w przekonaniu Thietmara piastowski władca nie miał prawa sięgać.

Można się zatem zastanawiać, czy w podobnych kategoriach nie należałoby oceniać także przywołane na początku relacje, zarzucające przyjmującym królewski tytuł piastowskim dynastom pychę i zuchwalstwo. Wydaje się bowiem, że potępienie przez ich autorów piastowskich koronacji i wroga reakcja na nie ze strony dworu cesarskiego w znaczącym stopniu, a może nawet przede wszystkim, wynikała z manifestowanych w akcie sakry aspiracji Piastów do nadania sprawowanej przez nich władzy sakralnego charakteru i osadzenia jej w związanej z godnością królewską tradycji liturgicznej. W tym miejscu warto jeszcze na moment powrócić do listu Matyldy. Jego redaktor przedstawiając rządy Mieszka II nie wymienił nazwy poddanego jego władzy ludu. W tekście mowa jest tylko o królu Mieszku. Nie wydaje się, aby wynikało to z jego nieuwagi. Można raczej sądzić, iż kwestia ta nie przedstawiała dla niego większego znaczenia. Jego zamiarem

49 Zob. Zbigniew DALEWSKI, Ritual and Politics: Writing History of Dynastic Conflict in Medieval Poland. Boston/Leiden 2008, s. $117 \mathrm{nn}$.

50 Thietmari Chronicon, s. 384 (VI 92): „Maior tamen est ei consuetudo periculose delinquendi, quam in salutary penitentia permanendi."

51 Por. Rob MEENS, Kirchliche Buße und Konfliktbewältigung: Thietmar von Merseburg näher betrachtet, w: Frühmittelalterliche Studien 41 (2007), s. 325 n. 
było bowiem zaprezentowanie panowania Mieszka nie jako króla polskiego, lecz jako króla chrześcijańskiego. Dał temu zresztą wyraz stwierdzając wprost, że Mieszko został powołany przez Boga do władania ludem świętym - ad regendum populum sanctum ${ }^{52}$. W realiach Europy Środkowej początków XI wieku tak definiowana godność królewska złączona była jednak nierozerwalnie z władzą sprawowaną przez królów niemieckich. Sens, a zarazem zakres sprawowanej przez nich rozumianej w ten sposób królewskiej zwierzchności, zarówno w znaczeniu praktycznym, jak i ideowym czy rytualnym, określało przekonanie o wynikającym z Boskiego nadania - uzewnętrznionym w liturgicznej ceremonii sakry - ich wyłącznym prawie do przewodzenia ludowi chrześcijańskiemu. W tak wykreślonych ramach dla piastowskich królów, pragnących mieć również udział w rządach nad świętym ludem Bożym i odwołujących się w celu zamanifestowania swoich praw w tym względzie do kopii Świętej Włócznie nie było miejsca. W rezultacie Piastowie musieli w latach trzydziestych XI wieku zrezygnować z godności królewskiej i zadowolić się tytułem książęcym.

\section{BIBLIOGRAFIA}

\section{Źródła}

Ademari Cabannensis Chronicon, wyd. Pascale BOURGAIN (Corpus Christianorum. Continuatio Mediaevalis. Vol. 129). Turnhout 1999.

Annales Hildesheimenses, wyd. Georg WAITZ (MGH Scriptores rerum Germanicarum in usum scholarum separatim editi. Vol. 8). Hannover 1878.

Annales Magdeburgenses, wyd. Georg Heinrich PERTZ u. a., in: MGH Scriptores (in Folio). Vol. 16: Historiae aevi Suevici. Hannover 1859, s. 107-196.

Annales Quedlinburgenses, wyd. Martina GIESE (MGH Scriptores rerum Germanicarum in usum scholarum separatim editi. Vol. 72). Hannover 2004.

Epistola Brunonis ad Henricum regem (Monumenta Poloniae Historica. Nova Series. Vol. 4, cz. 3), wyd. Jadwiga KARWASIŃSKA. Warszawa 1973.

Epistola Mathildis Suevae, wyd. Brygida KÜRBIS, w: Codex Mathildis. Liber officiorum cum foliis dedicationis (Monumenta Sacra Polonorum. Vol. 1). Kraków 2000.

Galli Anonymi Cronicae et gesta ducum sive principum Polonorum (Monumenta Poloniae Historica. Nova Series. Vol. 2), wyd. Karol MALECZYŃSKI. Kraków 1952.

Thangmari Vita Berwardi Episcopi Hildesheimensis, wyd. Georg Heinrich PERTZ, w: MGH Scriptores (in Folio). Vol. 4: Annales, chronica et historiae aevi Carolini et Saxonici. Hannover 1846.

Thietmari Merseburgensis episcopi Chronicon (MGH Scriptores rerum Germanicarum. Nova series. Vol. 9), wyd. Robert HOLTZMANN. Berlin 1935.

Wiponis Gesta Chuonradi II. imperatoris, wyd. Harry BRESSLAU (MGH Scriptores rerum Germanicarum in usum scholarum separatim editi. Vol. 61). Hannover/Leipzig 1915.

\section{Literatura}

Gerd ALTHOFF, Die Macht der Rituale: Symbolik und Herrschaft im Mittelalter. Darmstadt 2003.

Jerzy BANASZKIEWICZ, Otton III jedzie do Gniezna: o oprawie ceremonialnej wizyty cesarza w kraju i stolicy Polan, w: Idem, Trzy po trzy o dziesiątym wieku. Kraków 2014, s. 185-220.

Karen BLOUGH, The Lance of St Maurice as a Component the Early Ottonian Campaign against Paganism, w: Early Medieval Europe 24 (2016), s. 338-361.

Lothar BORNSCHEUER, Miseriae regum: Untersuchungen zum Krisen- und Todesgedanken in den herrschaftstheologischen Vorstellungen der ottonisch-salischen Zeit. Berlin 1968.

\footnotetext{
52 Epistola Mathildis Suevae, s. 139
} 
Cornelius Adrianus BOUMAN, Sacring and Crowning: the Development of the Latin Ritual for the Anointing of Kings and the Coronation of an Emperor before the Eleventh Century. Groningen/Djakarta 1957.

Egon BOSHOF, Die Vorstellung vom sakralen Königtum in karolingisch-ottonischer Zeit, w: Das Frühmittelalterliche Konigtum: ideelle und religiose Grundlagen, red. Franz-Reiner Erkens. Berlin/New York 2005, s. 331-358.

Zbigniew DALEWSKI, Die Heilige Lanze und die polnischen Insignien, w: Europas Mitte um 1000: Beitrage zur Geschichte, Kunst und Archaologie. T. 2, red. Alfried Wieczorek - Hans-Martin Hinz. Stuttgart 2000, s. 907-911.

Zbigniew DALEWSKI, Ritual and Politics: Writing History of Dynastic Conflict in Medieval Poland. Boston/Leiden 2008.

Zbigniew DALEWSKI, Sakralność władzy królewskiej pierwszych Piastów, in: Historia Slavorum Occidentis 14 (2017), s. 43-57.

Robert DESHMAN, The Exalted Servant: the Ruler Theology of the Prayerbook of Charles the Bald, w: Viator 11 (1980), s. 387-417.

Robert DESHMAN, Christus rex et magi reges: Kingship and Christology in Ottonian and Anglo-Saxon Art, w: Frühmittelalterliche Studien 10 (1976), s. 367-406.

Franz-Reiner ERKENS, Herrschersakralität im Mittelalter: von den Anfängen bis zum Investiturstreit. Stuttgart 2006.

Franz-Reiner ERKENS, Konrad II. (um 990-1039): Herrschaft und Reich des ersten Salierkaisers. Regensburg 1998.

Kurt GÖRICH, Eine Wende im Osten: Heinrich II. und Boleslaw Chrobry, w: Otto III. - Heinrich II.: eine Wende?, red. Bernd Schneidmüller - Stefan Weinfurter. Sigmaringen 1997.

Adolf HOFMEISTER, Die heilige Lanze, ein Abzeichen des alten Reiches. Breslau 1908.

Giovanni ISABELLA, Das Sakralkönigtum in Quellen aus ottonischer Zeit: unmittelbarer Bezug zu Gott oder Vermittlung durch die Bischöfe, w: Frühmittelalterliche Studien 44 (2011), s. 137-152.

Ludger KÖRNTGEN, Konigsherrschaft und Gottes Gnade: zu Kontext und Funktion sakraler Vorstellungen in Historiographie und Bildzeugnissen der ottonisch-fruhsalischen Zeit. Berlin 2001.

Hans-Walther KLEWITZ, Die heilige Lanze Heinrichs I., w: Deutsches Archiv für Geschichte des Mittelalters 6 (1943), s. 42-58.

Brygida KÜRBIS, Die Epistola Mathildis Suevae an Mieszko II. in neuer Sicht: ein Forschungsbericht, w: Frühmittelalterliche Studien 23 (1989), s. 318-338.

Brygita KÜRBIS, Epistola Mathildis Suevae, w: Codex Mathildis, s. 49-83.

Gerard LABUDA, Mieszko II król Polski (1025-1034): czasy przełomu w dziejach państwa polskiego. Kraków 1992.

Anatol LEWICKI, Mieszko II, w: Rozprawy Akademii Umiejętności, Wydział Historyczno-Filozoficzny 5 (1876), s. 87-208.

Henryk ŁOWMIAŃSKI, Poczatki Polski: polityczne i społeczne procesy kształtowania się narodu do początku wieku XIV, t. 6, cz. 1. Warszawa 1985.

Rob MEENS, Kirchliche Buße und Konfliktbewältigung: Thietmar von Merseburg näher betrachtet, w: Frühmittelalterliche Studien 41 (2007), s. 317-330.

Rob MEENS, Penance in Medieval Europe, 600-1200. Cambridge 2014.

Roman MICHAŁOWSKI, The Gniezno Summit: the Religious Premises of the Founding of the Archbishopric of Gniezno. Leiden/Boston 2016.

Roman MICHAŁOWSKI, Christianisation of the Piast Monarchy in the 10th and 11th Centuries, w: Acta Poloniae Historica 101 (2010), s. 14-32.

Roman MICHAŁOWSKI, The Nine-Week Lent in Boleslaus the Brave's Poland: a Study of the First Piasts' Religious Policy, w: Acta Poloniae Historica 89 (2004), s. 5-50.

Roman MICHAŁOWSKI, Princeps fundator: studium z dziejów kultury politycznej w Polsce X-XIII wieku. Warszawa 1989.

Janet Loughland NELSON, Kingship and empire, w: Carolingian Culture: Emulation and Innovation, red. Rosamond McKitterick. Cambridge 1994, s. 52-87.

Marcin Rafal PAUK, Washing Hands in a Sinner's Blood: Ducal Power, Law and Religious Zeal in the Process of Central European Christianization - Preliminary Remarks, w: Leben zwischen und mit den 
Kulturen: Studien zu Recht, Bildung und Herrschaft in Mitteleuropa, red. Renata Skowrońska - Helmut Flachenecker. Toruń 2015, s. 23-34.

Andrzej PLESZCZYŃSKI, The Birth of Stereotype: Polish Rulers and their Country in German Writings c. 1000 A.D. Leiden/Boston 2011.

Aniela POSPIESZYŃSKA, Mieszko II a Niemcy, w: Roczniki Historyczne 14 (1938), s. 239-295.

Mieczysław ROKOSZ, Wawelska włócznia Bolesława Chrobrego: przegląd problematyki, w: Rocznik Krakowski 15 (1989), s. 17-44.

Rudolf SCHIEFFER, Mediator cleri et plebis: zum geistlichen Einfluß auf Verständnis und Darstellung des ottonischen Königtums, w: Herrschaftsrepräsentation im ottonischen Sachsen, red. Gerd Althoff Ernst Schubert. Sigmaringen 1998, s. 344-361.

Reinhard SCHNEIDER, Die Königserhebung Heinrich II. im Jahre 1002, w: Deutsches Archiv für Erforschung des Mittelalters 28 (1972), s. 74-104.

Walther SCHLESINGER, Erbfolge und Wahl bei der Königserhebung Heinrichs II. 1002, w: Festschrift für Hermann Heimpel zum 70. Geburtstag. T. 3. Göttingen 1972, s. 1-36.

Percy Ernst SCHRAMM, Der Ablauf der deutschen Königsweihe nach dem 'Mainzer Ordo' (um 960), w: Idem, Kaiser, Könige und Päpste: Gesammelte Aufsätze zur Geschichte des Mittelalters. T.3. Stuttgart 1969, s. 59-107.

Percy Ernst SCHRAMM, Die 'Heilige Lanze', Reliquie und Herrschaftszeichen des Reiches und ihre Replik in Krakau: ein Überblick über die Geschichte der Königslanze, w: Idem., Herrschaftszeichen und Staatssymbolik: Beiträge zu ihrer Geschichte vom dritten bis zum sechszehnten Jahrhundert. Stuttgart 1955, s. 492-537.

Klaus SCHREINER, Nudis pedibus: Barfüßigkeit als religiöses und politisches Ritual, w: Formen und Funktionen öffentlicher Kommunikation im Mittelalter, red. Gerd Althoff. Stuttgart 2001, s. 53-124.

Mechthild SCHULZE-DÖRRLAMM, Die Heilige Lanze in Wien: die Frühgeschichte des karolingischottonisch Herrschaftszeichens aus archäologischer Sicht, w: Jahrbuch des Romisch-Germanischen Zentralmuseums 58 (2011), s. 707-742.

Dariusz Andrzej SIKORSKI, Kościół w Polsce za Mieszka I i Bolesława Chrobrego: rozważania nad granicami poznania historycznego. Poznań 2011.

Edward SKIBIŃSKI, Koronacje pierwszych Piastów w najstarszych źródłach narracyjnych, w: Gnieźnieńskie koronacje królewskie i ich środkowoeuropejskie konteksty, red. Józef Dobosz - Marzena Matla Leszek Wetesko. Gniezno 2011, s. 213-234.

Jerzy STRZELCZYK, Zjazd gnieźnieński. Wrocław 2000.

Błażej ŚLIWIŃSKI, Bezprym: pierworodny syn pierwszego krola Polski (986 - zima/wiosna 1032). Kraków 2014.

Stefan WEINFURTER, Der Anspruch Heinrichs II. auf die Königsherrschaft, w: Papstgeschichte und Landesgeschichte: Festschrift für Hermann Jakobs zum 65. Geburtstag, red. Joachim Dahlhaus - Armin Kohnle. Köln/Weimar/Wien 1995, s. 121-134.

Stefan WEINFURTER, Heinrich II. (1002-1024): Herrscher am Ende der Zeiten. Regensburg 2002.

Stefan WEINFURTER, Kaiser Heinrich II. und Bolesław Chrobry: Herrscher mit ähnlichen Konzepten?, w: Questiones Medii Aevi Novae 9 (2004), s. 5-25.

Stefan WEINFURTER, Idee und Funktion des 'Sakralkönigtums' bei den ottonischen und salischen Herrschern (10. und 11. Jahrhundert), w: Legitimation und Funktion des Herrschers: vom ägyptischen Pharao zum neuzeitlichen Diktator, red. Rolf Gundlach - Hermann Weber. Stuttgart 1992, s. 99-127.

Stefan WEINFURTER, Zur 'Funktion' des ottonischen und salischen Königtums, w: Mittelalterforschung nach der Wende, red. Michael Borgolte. München 1995, s. 249-361.

Przemysław WISZEWSKI, Domus Bolezlai: Values and Social Identity in Dynastic Traditions of Medieval Poland (c. 966-1138). Leiden/Boston 2010.

David A. WARNER, Henry II at Magdeburg: Kingship, Ritual and the Cult of Saints, w: Early Medieval Europe 3 (1994), s. 135-166.

Gunther WOLF, Heilige Lanze: Longinus-, Kreuznageloder Mauritius-Lanze, w: Idem., Satura mediaevalis: Gesammelte Schriften herausgegeben zum 65. Geburtstag. T. 2: Ottonenzeit. Heidelberg 1995.

Herwig WOLFRAM, Konrad II. 990-1039: Kaiser dreier Reiche. München 2000. 